\title{
Three-year prevalence of healthcare-associated infections in Dutch nursing homes
}

\author{
A Eikelenboom-Boskamp ${ }^{1,2^{*}}$, J Cox-Claessens ${ }^{3}$, P Boom-Poels ${ }^{4}$, M Drabbe $^{5}$, R Koopmans $^{6}$, A Voss $^{1,2}$ \\ From International Conference on Prevention \& Infection Control (ICPIC 2011) \\ Geneva, Switzerland. 29 June - 2 July 2011
}

\section{Introduction / objectives}

The objective of this study was to measure the prevalence of HAIs (overall as well as per type of care) and to gain insight into infection prevention and control and antimicrobial use in Dutch nursing homes.

\section{Methods}

We conducted an annual, one-day prevalence study of HAIs among nursing home residents in the Nijmegen region over three consecutive years (2007-2009). Modified definitions based on CDC-criteria were used for bloodstream infection, lower respiratory tract infection, bacterial conjunctivitis and gastroenteritis. For urinary tract infections (UTI), criteria established by the Dutch Association of Elderly Care Physicians were used. Also resident characteristics were recorded. Data collection and resident assessment were done by the attending elderly care physicians.

\section{Results}

The prevalence of HAIs over the three years was $6.7 \%$, $7.6 \%$ and $7.6 \%$, respectively. UTI was the most prevalent HAI with an overall prevalence of $3.8 \%$ and most UTI were not catheter-asscociated. Overall most HAIs occurred among residents of rehabilitation units. On average, antibiotics were used in $6.6 \%$ of the residents.

\section{Conclusion}

This is the first prevalence study of HAIs in Dutch nursing homes, which became an important cornerstone of infection control programs in nursing homes, started in our region (see additional abstract). Based on the prevalence results, incidence studies for UTI need to be done in order to find risk-factors for their occurrence.

${ }^{1}$ Medical Microbiology, Radboud University Medical Centre, Netherlands Full list of author information is available at the end of the article

\section{Disclosure of interest}

None declared.

\begin{abstract}
Author details
${ }^{1}$ Medical Microbiology, Radboud University Medical Centre, Netherlands. ${ }^{2}$ Medical Microbiology and Infectious Diseases, Canisius Wilhelmina Hospital, Netherlands. ${ }^{3}$ ZZG Zorggroep, nursing home Margriet, Nijmegen, Netherlands. ${ }^{4}$ Zorgcentra Pantein, nursing home Madeleine, Boxmeer, Netherlands. ${ }^{5}$ Zorggroep Maas en Waal, nursing home Waelwick, Ewijk, Netherlands. ${ }^{6}$ Primary and Community Care, Radboud University Medical Centre, Nijmegen, Netherlands.
\end{abstract}

Published: 29 June 2011

doi:10.1186/1753-6561-5-S6-P158

Cite this article as: Eikelenboom-Boskamp et al:: Three-year prevalence of healthcare-associated infections in Dutch nursing homes. BMC Proceedings 2011 5(Suppl 6):P158.
Submit your next manuscript to BioMed Central and take full advantage of:

- Convenient online submission

- Thorough peer review

- No space constraints or color figure charges

- Immediate publication on acceptance

- Inclusion in PubMed, CAS, Scopus and Google Scholar

- Research which is freely available for redistribution
C Biomed Central 